\title{
A Message from the Editor
}

This year, 2017, marks the 80th anniversary of the foundation of the International Society of Criminology in Rome, Italy. This act represented the culmination of a growing interest in the issue of crime, punishment, crime prevention and of the first attempts to use a scientific approach to the understanding of criminal behavior and to possible intervention to control it. During the 19th and early 20th centuries there was considerable scholarly activity in the field. Of course, it reflected the conditions of science and certain cultural and social biases at the time. International congresses of criminal anthropology were held with the support and participation of French, Italian and German scholars. At that time, criminal anthropology, as defined by one of the recognized founders of criminology, Cesare Lombroso, included all aspects of the scientific study of the criminal phenomenon.

The many congresses held between 1856 and 1911 in Rome, Paris, Brussels, Geneva, Amsterdam, Turin and Cologne gave impetus to the movement and support to the debate on the explanation of criminal behavior and on how to prevent it. World War I disrupted this promising activity. International contacts resumed after the end of the war and soon there was a call for more worldwide coordination of academic and research activities in the field. At an international meeting of criminologists in Paris in 1934, the decision to create an international association was taken. An Italian lawyer and professor and a strong proponent of the idea, Benigno di Tullio, was given the task of formalizing an agreement, founding a scholarly association and organizing the first International Congress of Criminology. Thus, on 16 July 1937 the International Society of Criminology was founded in Rome, Italy with the support and participation of several luminaries of the time. Among the founders were Father Agostino Gemelli, the founder and president of the Catholic University of Milano, and Arturo Rocco, professor of Penal Law and Criminal Procedure at the University of Rome and the author of the 1930 Italian Penal Code that influenced the writing and adoption of penal codes in various countries, especially in South America. Mariano d'Amelio, first president of the Italian Court of Cassation, was elected President; Giovanni Novelli, also with the Italian Court of Cassation, Vice-President; and Professor Benigno di Tullio, Secretary General. The offices of the Society were located in Via Giulia 52, Rome.

At that time, the Society was conceived mostly as a federation of various national and international societies of criminal biology, criminal anthropology and criminology active in many countries of Europe and South America. Its main objective and distinctive feature was to foster and support international collaboration in the field. Its main publication was called the Review of Penitentiary Law.

The first International Congress of Criminology was also held in Rome on 3-8 October 1938. According to official reports on the Congress, it was attended by 1,200 professors and scholars, official delegations of other associations and even 33 official 
state delegations. The United States and the Soviet Union did not take part in these activities. World War II disrupted the activities of the Society. It was not until 1949 that the Society was revived and its statute adopted. A further impulse to the reorganization of the Society was provided by the Second International Congress held at the Sorbonne in Paris from 10 to 19 September 1950.

Throughout the decades since then, the Society truly became the leading global network of experts researching and teaching on crime, deviance, and their root causes and providing criminal justice solutions and innovations, grounded in the full respect of human rights and the rule of law.

Under the auspices of the Society, World Congresses of Criminology have been held regularly throughout the decades. In this century congresses were held in Rio de Janeiro (2003), Philadelphia (2005), Barcelona (2008), Kobe, Japan (2011), Monterrey, Mexico (2014) and Delhi Capital Region, India (2016). All were successful, heavily attended, and well covered by the media. The next XIX Congress will be held in Turin, Italy from 23 to 27 September 2018.

An important contribution to the development and international recognition of criminology has been the official publication of the Society, renamed in 1961 the International Annals of Criminology. All past volumes of the Annals have been digitized and are now available online, by the German Criminological Information Collection and Distribution Center (Fachinformationsdienst Kriminologie; FIDKrim) thanks to a grant by the German Foundation for Research and the supportive intervention of the Honorary President of the International Society of Criminology, Professor Emeritus Hans Jürgen Kerner of the University of Tübingen. This is an important asset for the Society and its members. Presently, the International Annals of Criminology are being published by the Society in cooperation with Cambridge University Press and are fully refereed.

This is an important and vital step for the evolution of the Annals to meet today's norms and requirements to become even more so a truly prestigious and influential scholarly publication.

A major goal of the journal is to be genuinely international and provide a respected publication outlet for scholars from all over the world. Too often scholarly journals tend to publish material originating in Europe, the United States and other "advanced" countries.

The Annals want to judiciously identify valuable contributions by scholars in areas of the world that are at times overlooked and go unrecognized. Discovering and showcasing new talents, original approaches, local solutions and empirical studies that reveal different realities are a priority for the new Annals. This way, the journal will be truly international, not just in name but in editorial policy, content, authorship and readership.

It is very fitting that this venerable publication is now entering this new phase, adapting itself to current academic realities and demands, thus acquiring increased importance and respect, while we celebrate the 80th anniversary of the founding of the Society.

It is very pertinent at this point to recognize that indeed we stand on the shoulders of giants. The Society and the Annals have survived throughout the decades thanks to the commitment, hard work, and sacrifice of great scholars and colleagues. I want to recognize their contributions, diligence, creativity and loyalty to the Society, the Annals and criminology. While it is not possible to mention most of them here, I want to express our thanks to the immediate past Editor in Chief, Georges Kellens, professor emeritus of the University of Liège, Belgium who for years guaranteed with 
his discreet and diligent efforts the timely publication of the Annals. We owe Professor Kellens a great debt of gratitude and we gladly underline his major role in steering the Annals editorially in recent years. We also recognize the major contribution of Dr Hans Jürgen Kerner, professor emeritus of the University of Tübingen, for the digitizing of all the past volumes of the Annals as already mentioned above. This will ensure that the legacy of the Annals will continue to influence and inspire criminologists worldwide for decades to come.

I take this opportunity to thank all the members of the current Editorial Board of Advisors for accepting to serve and assist the Editorial Office in producing a major scholarly journal. Many special thanks also to the referees that have donated their time and skills to review and evaluate papers offered for publication. With their input, suggestions and recommendations, we can rest assured that the content of the Annals will always reflect the best scholarly work internationally.

Also, a warm "thank you" to the colleagues who have sent their precious work for possible publication in the Annals. Their confidence, trust and respect for the Annals are deeply appreciated.

Moreover, a sincere "thanks" to the editors and staff of Cambridge University Press for their support, assistance and care in working with the Society's Editorial Office to produce, market and distribute the Annals worldwide. Their skills, patience, dedication and superb delivery are very much appreciated.

Importantly, the International Society of Criminology is proud to announce that the 19th World Congress of Criminology will take place in Turin (Torino), Italy from 23 September (arrival) to 27 September 2018, in commemoration of the first Congress held in Rome, Italy in October 1938. The founder of the Institute of Criminology at Cambridge University, Sir Leon Radzinowicz (1906-1999) wrote in his book, The Spiral of Crime (Giuffre 1981) that: "The contribution (of Italian criminology) to the theory and methodology of contemporary criminology is enormous and the impact, direct or indirect, hidden or overt, which has had around the world, is impressive." Yet this has never been truly acknowledged; on the contrary it has been forgotten, and must be remembered. This anniversary of the founding of the International Society of Criminology is the right opportunity to do so. A cordial invitation is extended to the international criminology and criminal justice community for active participation in this event.

Finally, scholars, researchers, professionals and policymakers in criminology and criminal justice are invited to consider the Annals as their preferred outlet for publishing their work and to send it to the Editorial Office of the International Society of Criminology for evaluation by the referees.

Thank you! We at the Editorial Office look forward to working with you!

\author{
Emilio C. Viano, Editor \\ International Society of Criminology, Washington, DC, USA \\ Email emilio.viano@gmail.com
}

Cite this article: Viano, E. C. 2017. A Message from the Editor. International Annals of Criminology 55: 1-3, doi:10.1017/cri.2017.8 